\title{
Planetary Health and the Future of Human Capacity: The Increasing Impact of Planetary Distress on the Human Brain
}

\author{
Chong Chen * ${ }^{*}$ and Shin Nakagawa \\ Division of Neuropsychiatry, Department of Neuroscience, Yamaguchi University Graduate School of Medicine, \\ Yamaguchi 755-8505, Japan; snakaga@yamaguchi-u.ac.jp \\ * Correspondence: cchen@yamaguchi-u.ac.jp; Tel.: +81-836-22-2255; Fax: +81-836-22-2253
}

Received: 20 October 2018; Accepted: 20 November 2018; Published: 22 November 2018

\begin{abstract}
All awareness, thoughts, emotions, perceptions, memories, actions-everything that encompasses our human capacity and reality-are mediated through the biological interface of our brains. While the source of consciousness remains a fundamental and elusive question, it is also inescapable that threats to biological health can compromise any and all aspects of psychological and neurological functioning, from the first moments of life. The effects of environmental threats to specific aspects of individual brain health are well recognized, yet precious little attention is given to the collective effects of planetary-scale environmental damage, and the erosion of numerous planetary systems, on the biology of the human brain. Although, these are likely to vary widely with individual circumstances, it is also inevitable that the 'dysbiotic drift' (increasing life in distress) at the planetary scale is reflected at the personal scale, with a collective shift towards increased biological stress of all kinds. Here, we make the case that 'planetary distress' is directly implicated in a collective increase in 'personal distress', and that multifaceted biological pressures, as well as psychological pressures, are implicated in the mental health crisis and predisposition to numerous disorders in brain development, functioning and aging. In turn, this has implications for every aspect of health, capacity, and the very essence of human experience for generations to come. Viewed on this scale, we call for a quantum shift in efforts to address the many factors affecting brain health, ranging from air pollution to disappearing greenspace. These all stem from ecological imbalance and point to a unifying need to restore planetary health. Ultimately, the future of human capacity depends on this.
\end{abstract}

Keywords: air pollution; biodiversity; brain; ecology; environmental degradation; greenspace; natural environments; neuroscience; planetary health; psychiatry

\section{Introduction}

We may be far greater than our biology, but it is our biology that limits us, particularly if it is more limited than it needs to be. In this, the health of our brains is arguably one of the most fundamental aspects of human potential at both the personal and planetary scale. Although optimizing conditions for brain health throughout life has long been a concern at the personal and public health level, it is now vital to expand this agenda to a multilateral planetary perspective, in the face of devastating damage to the many planetary systems on which we depend. In short, this calls for greater attention to the collective effects of planetary-scale environmental damage on the health of the human brain.

Specifically, by brain health, we refer to both cognitive (related to memory and information processing) and affective/motivational (related to mood and emotion) health, as well as underlying neurobiological health (including neurotransmission and neuromorphology). These are the prerequisites of intelligence [1], creativity/innovation [2], and mental health [3], all fundamental 
for human capacity—-the essential basis of all that makes us human and even our ability to imagine ourselves beyond biology to explore questions of consciousness.

Yet, at no time in history have we faced such multifaceted large-scale environmental threats to the foundations of our biology. Although, the effects of environmental threats will vary widely with geographical and individual circumstances, these is little doubt that increasing life in distress ('dysbiotic drift') at the planetary scale is reflected in increased biological stress at the personal scale [4,5].

It has become increasingly evident that many factors associated with 'planetary distress' may be implicated in a large scale collective increase in 'personal distress' - either directly or indirectlythrough effects on brain health. While the most obvious among these may be air and water pollution [6] and declining access to greenspace, which are the core focus of this review (below), many other factors affecting brain health are also adversely implicated in changing planetary conditions and ways of human living. These include food systems and dietary patterns $[7,8]$, physical activity levels $[9,10]$, psychological stress [11,12], sleep [13,14], socioeconomic status [15] and disruption to the many microbial ecosystems that support human and environmental health [5].

In this review, we present evidence to support the argument that 'planetary distress' is directly implicated in a collective increase in 'personal distress' and that these effects are mediated, at least in part, by effects on the brain. This is likely to be compounded by the distinct psychological pressures (known as 'solastalgia' [16]) experienced by humans when they experience damage and degradation of their living environment, which will have biological effects. These multifaceted biological pressures, as well as mounting psychological pressures, pose major threats to the human experience and to human capacity. This all serves as a call for large scale changes to protect both the future of humanity and our planetary environment, and the awareness that these cannot be separated.

\section{Environmental Pollution Harms the Brain through Multiple Pathways}

Exposure to air pollution has been associated with cognitive impairment across the lifespan. For instance, as concluded by a recent systematic review [17], exposure during childhood is associated with delayed mental development, poorer cognitive abilities, and lower academic achievement, while exposure in the elderly is associated with faster cognitive decline.

Air pollution also threatens our mental health. A case-crossover analysis of over 20,000 suicide deaths in Belgium reported that air pollution triggered suicide during summer [18]. In this study, exposure to particulate matter 10 or $\mathrm{PM}_{10}$ - particles with a diameter of 10 micrometers or less—was estimated to raise the risk of suicide in children (aged 5 to 14 years) by $45 \%$ and in the elderly (aged over 85 years) by $17 \%$.

These epidemiological data do not stand alone. They are in accordance with a large amount of neuroscientific data showing environmental pollution harms the brain.

Employing magnetic resonance imaging (MRI), a study of children living in highly polluted Mexico City indicated structural damage in the prefrontal cortex (PFC; [19]). A report from the Framingham Offspring Study estimated that a $2-\mu \mathrm{g} / \mathrm{m}^{3}$ increase in $\mathrm{PM}_{2.5}$-fine particles with a diameter of 2.5 micrometers or less-was associated with a $0.32 \%$ reduction in the total cerebral brain volume, suggesting more severe age-associated brain atrophy [20]. If this estimation can be generalized, it has striking implications. According to the World Health Organization (WHO) [21], in 2016, the average concentrations of $\mathrm{PM}_{2.5}$ in the urban areas of the United States, Mexico, and India were $7.6,20.9$ and $68.0 \mu \mathrm{g} / \mathrm{m}^{3}$, respectively. Here, you can do the calculation yourself and see the potential consequence indicated by the above report.

Air pollution affects the brain through multiple pathways (see Figure $1 ;[22,23]$ ). Once inhaled, pollutant particles can enter the brain directly via the nasal olfactory pathway, or indirectly through the circulatory system after they penetrate the lung tissue. Magnetite pollutant particles which are $<200 \mathrm{~nm}$ in diameter have been detected in the frontal cortex of young adults living in Mexico City who died in fatal accidents [24]. A similar amount of magnetite pollutant particles has also been identified in older adults with severe to moderate Alzheimer's disease [24]. 


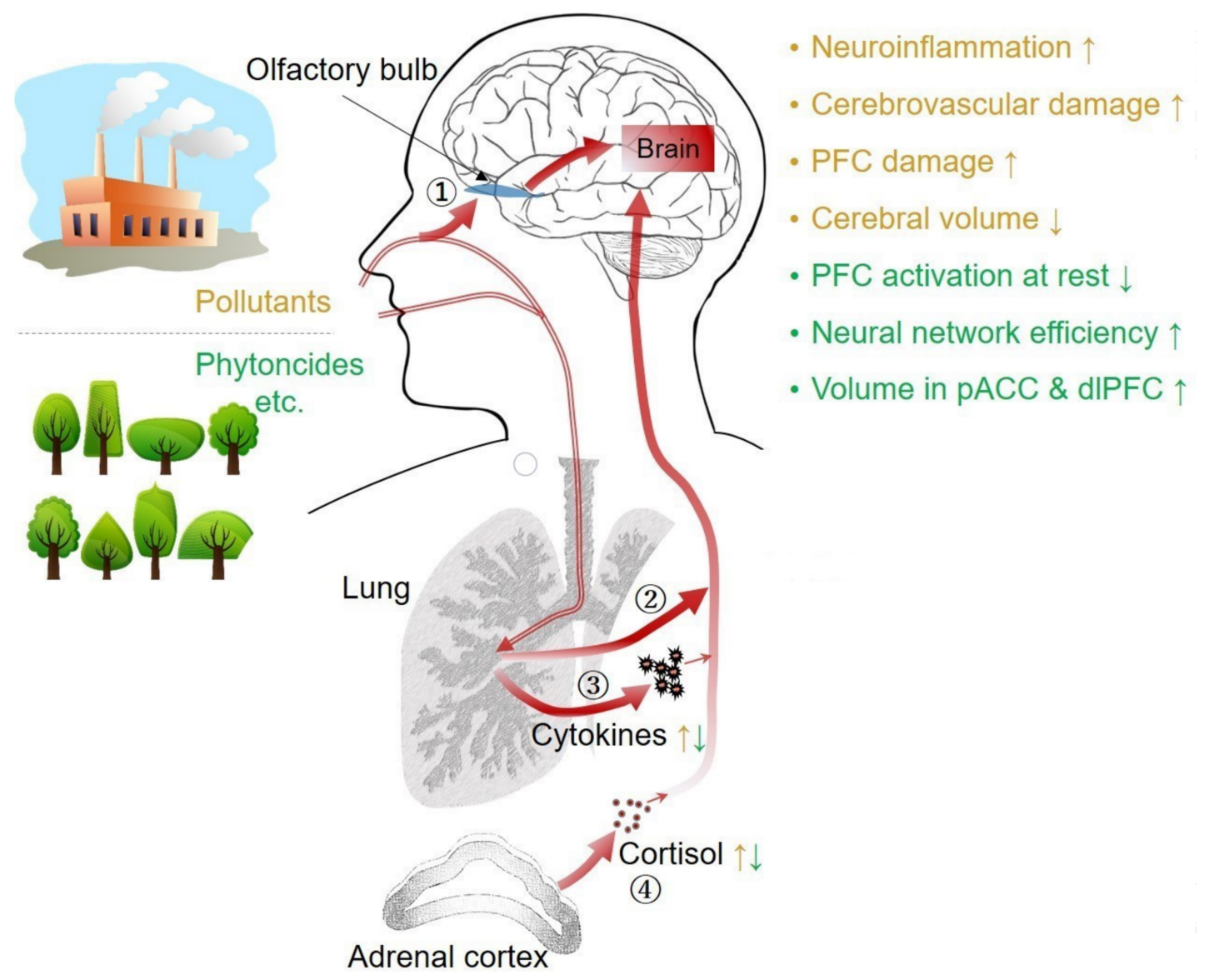

Figure 1. Air pollution and greenspace's multiple pathways to the brain. Once inhaled, pollutant particles can enter the brain directly via the nasal olfactory pathway (1) or indirectly through the circulatory system after they penetrate the lung tissue (2). They cause inflammation in the nose and lungs and release pro-inflammatory cytokines into the circulation (3). In addition, they activate the hypothalamus-pituitary-adrenal (HPA) axis and increase the blood levels of stress hormones, including cortisol (4). Both pro-inflammatory cytokines and cortisol can reach the brain. Greenspace produces phytoncides and other health-promoting chemicals such as negative air ions, which affect the brain through similar pathways but in the opposite direction. For a more comprehensive review of the pathways, see $[22,23,25]$.

Pollutant particles also cause local inflammation in the nose and lungs which eventually lead to systemic inflammation. The latter causes neuroinflammation and cerebrovascular damage. An autopsy study of healthy children and young adults living in highly polluted Mexico City who died suddenly, found elevated pro-inflammatory cytokines (e.g., IL1-b) and endothelial activation in the olfactory bulb, frontal cortex, substantia nigra, and vagus nerves, compared to those living in less polluted cities [26]. Neuroinflammation and cerebrovascular damages cause neuronal death and play a pivotal role in the development of many neurological and psychiatric diseases, including Alzheimer's disease [27,28], Parkinson's disease [29,30], depression [31,32], and schizophrenia [33,34].

Pollutant particles may also activate the hypothalamus-pituitary-adrenal (HPA) axis, a major neuroendocrine system we use to deal with environmental challenges and psychological stress. A study conducted in Shanghai followed 40 college students for a period of five months [35]. During the study period, the concentration of $\mathrm{PM}_{2.5}$ varied substantially between 12.2 and $80.5 \mu \mathrm{g} / \mathrm{m}^{3}$, with an average of $41.1 \mu \mathrm{g} / \mathrm{m}^{3}$. It was found that when the concentration of $\mathrm{PM}_{2.5}$ in the city air increased, people's blood levels of stress hormones, including corticotropin-releasing hormone, adrenocorticotropic hormone, and cortisol, were subsequently elevated within one or two days. This suggests that the 
short-term variation of $\mathrm{PM}_{2.5}$ at the 24-hour level was sufficient to cause fluctuations in the levels of stress hormones. How $\mathrm{PM}_{2.5}$ triggered the HPA axis remains unclear, but perhaps our body 'feels' air pollutions just like psychological stress. Notably, chronic activation of the HPA axis has been linked to neuroinflammation and many neurological and psychiatric diseases $[9,11]$.

Not only air pollution, but other forms of pollution such as those caused by chemicals [6], noise [36], heat/climate change [37], and nighttime light [38] have also been associated with elevated systemic inflammation and/or cognitive and mental health problems. Although these remain less studied compared to air pollution, they are increasingly recognized for their adverse effects and are increasingly becoming the subject of further investigation.

\section{Greenspace Benefits the Brain through Multiple Pathways}

In contrast, exposure to cleaner, greener natural environments-such as forests and parks-has been shown to promote the health of the brain through multiple pathways (see Figure 1; $[39,40]$; for a more comprehensive review, see [25]). Plants not only reduce environmental pollution but also produce many health-promoting substances, including phytoncides and negative air ions. They also contain diverse microbes that are important to our health.

In general, rural areas are greener and less polluted compared to urban areas [41]. Lederbogen et al. [42] found that in response to a social evaluative threat, currently living in a rural area is associated with lower activation in the amygdala, suggesting higher resiliency. Meanwhile, more years of rural upbringing is associated with lower activation in the perigenual anterior cingulate cortex (pACC) and higher functional connectivity between the pACC and the amygdala, which suggests a more efficient neural network for emotional control. Using MRI, Haddad et al. [43] found that more years living in rural rather than urban areas in the first 15 years of life is associated with larger gray matter volume in the pACC and the dorsolateral prefrontal cortex (dIPFC). This implies a neuroprotective effect of being raised in rural areas.

Several neuroimaging studies have indicated beneficial effects on the brain of even brief nature contact. Studies using functional near-infrared spectroscopy (fNIRS) reported that 20 minutes of forest walking [44] or 3 minutes of gardening activities [45] reduced activation of the PFC, which is interpreted as a relaxing effect. Another study using functional magnetic resonance imaging (fMRI) reported that a 90-minute walk in a natural setting decreased the activity of the subgenual PFC and the pACC [46]. The subgenual PFC and the pACC typically become more active under negative emotions such as anxiety and depression (see Reference [25]).

Nature contact such as forest walking also boosts immunity and reduces the level of pro-inflammatory cytokines $[47,48]$. Furthermore, forest walking attenuates stress responses and reduces the level of stress hormones, particularly cortisol (for a review, see [49]). In addition, natural environments also promote health by providing opportunities for physical exercise and social contact [50]. Furthermore, contact with healthy natural environments is being increasingly shown to promote healthier human microbiomes-now recognized as an essential component of all aspects of health, including brain health [5].

As a result, a large, growing number of epidemiological studies from around the world have reported that people living in greener residential surroundings (typically within a 1-3-kilometer radius) have a lower incidence of many diseases, both physical and mental [40,51]. They also possess higher cognitive abilities and are better-tempered, more altruistic, more friendly, more satisfied with their lives, and live longer [40,51].

\section{The Future of Human Potential Depends on Planetary Health}

We are living in a world of increasing dichotomies and extremes. Humanity is enjoying unprecedented growth in technology and rapid economic development. Yet, this has occurred in tandem with the many detrimental effects of urbanization, industrialization, and extreme social inequality-all coupled with profound physical and psychological distress. 
The growing pressure of human activities is associated with the clear deterioration of many planetary systems; in essence we are living on a planet in distress [52] and many aspects of this are getting worse. According to the World Bank [53], the increase of $\mathrm{PM}_{2.5}$ air pollution has accelerated in the past decades (Figure 2). Now 91\% of the world's population lives in places where air quality exceeds WHO guideline limits—mostly in the Eastern Mediterranean and South-East Asia [54].

PM2.5: World Trend

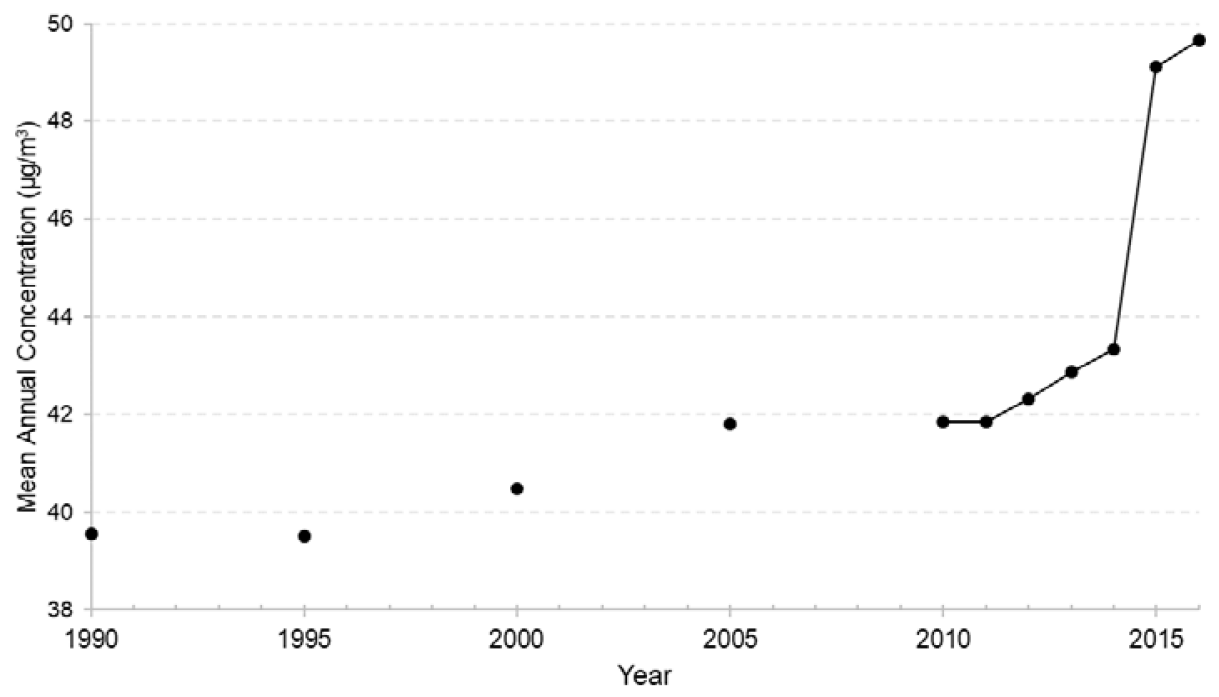

Figure 2. $\mathrm{PM}_{2.5}$ air pollution, mean annual exposure $\left(\mu \mathrm{g} / \mathrm{m}^{3}\right)$. Data source: World Bank [53].

Adding to this, our planet is experiencing erosion of many of the protective and buffering systems. For instance, forests as a major component of the green, protective natural environment have been disappearing year by year at unprecedented speed (Figure 3).

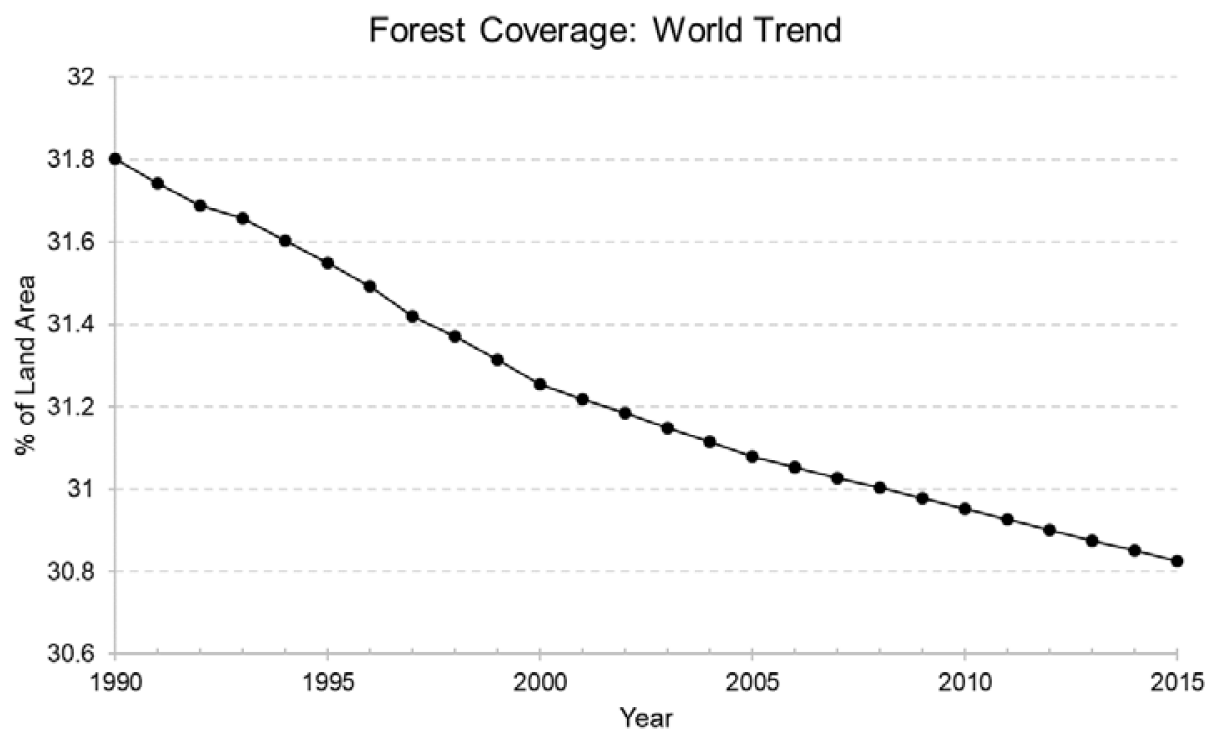

Figure 3. Forest coverage (\% of land area). Data source: World Bank [55].

This reflects the 'dual burden' of dysbiotic drift, discussed by Prescott and Logan in the introduction of this Special Issue. Both humanity and planetary systems are suffering the compounding additive burden of increasing adverse exposures (e.g., pollution) on one hand, as well as the effects of decreasing protective exposures (e.g., loss of biodiversity due to disappearing greenspace) on the 
other. As we have shown, this echoes through to the cellular level as we consider the impact on human health, including our brains.

Even further than this, we argue that we are also haunted by a 'third degree of burden'-our increasing vulnerability, as a consequence of these many exposures. It has been reported that the detrimental effect of air pollution on cognitive performance actually becomes more evident as we age [56]. In mice, acute exposure to ozone induces neuroinflammation to a greater degree in the aged compared to in the young [57]. Thus, our brains become more vulnerable to environmental problems as we get older. This raises a serious concern as the world population is expected to age- and has already been aging—quickly (Figure 4).



Figure 4. Percentage of population aged 60 years or over, from 1980 to 2050. Data source: United Nations [58].

Moreover, there may be transgenerational effects yet to be appreciated, as has been seen with other body systems, which compound both the effects and the vulnerabilities to adverse environments across generations, as has been seen with obesity and other noncommunicable diseases [59].

Already, neurological and psychiatric disorders have become a leading cause of the global burden of disease [60,61], with huge economic losses and health care costs reducing resources available to manage environmental damage and pollution control. This must be seen as a warning sign of neurobiological effects of collective stress, and the already shifting patterns of human biology.

This calls for large-scale planetary efforts which address the 'three degrees of burden', by reducing adverse exposures, increasing protective factors and improving resilience-towards sustainable development [62], before it is too late. For this to occur, it is vital to understand and appreciate how the future of the planet and humanity are interdependent.

There is no question that the crisis in human identity extends far beyond biological domains, yet without addressing the pressures that are magnifying our biological limits we will not have the resources or the capacity to overcome these challenges.

Author Contributions: Conceptualization, C.C. and S.N.; Methodology, C.C.; Investigation, C.C.; Data Curation, C.C.; Writing-Original Draft Preparation, C.C.; Writing-Review \& Editing, C.C. and S.N. 
Funding: This research received no external funding.

Acknowledgments: We thank the guest editors Susan Prescott and Alan C. Logan and three anonymous reviewers for their thoughtful comments and constructive suggestions.

Conflicts of Interest: C.C. is the author of Chocolate and the Nobel Prize, Fitness Powered Brains, and Cleverland. S.N. declares no conflicts of interest.

\section{References}

1. Nisbett, R.E. Intelligence and How to Get It: Why Schools and Cultures Count; WW Norton \& Company: New York, NY, USA, 2009.

2. Jauk, E.; Benedek, M.; Dunst, B.; Neubauer, A.C. The relationship between intelligence and creativity: New support for the threshold hypothesis by means of empirical breakpoint detection. Intelligence 2013, 41, 212-221. [CrossRef] [PubMed]

3. Beck, A.T.; Alford, B.A. Depression: Causes and Treatment, 2nd ed.; University of Pennsylvania Press: Philadelphia, PA, USA, 2014.

4. Logan, A.C. Dysbiotic drift: Mental health, environmental grey space, and microbiota. J. Physiol. Anthropol. 2015, 34, 23. [CrossRef] [PubMed]

5. Prescott, S.L.; Wegienka, G.; Logan, A.C.; Katz, D.L. Dysbiotic drift and biopsychosocial medicine: How the microbiome links personal, public and planetary health. Biopsychosoc. Med. 2018, 12, 7. [CrossRef] [PubMed]

6. Landrigan, P.J.; Fuller, R.; Acosta, N.J.; Adeyi, O.; Arnold, R.; Basu, R.; Baldé, A.B.; Bertollini, R.; Bose-O'Reilly, S.; Boufford, J.I. The Lancet Commission on pollution and health. Lancet 2018, 391, 462-512. [CrossRef]

7. Gómez-Pinilla, F. Brain foods: The effects of nutrients on brain function. Nat. Rev. Neurosci. 2008, 9, 568. [CrossRef] [PubMed]

8. Chen, C. Chocolate and the Nobel Prize: The Book of Brain Food; Brain \& Life Publishing: London, UK, 2018.

9. Chen, C.; Nakagawa, S.; An, Y.; Ito, K.; Kitaichi, Y.; Kusumi, I. The exercise-glucocorticoid paradox: How exercise is beneficial to cognition, mood, and the brain while increasing glucocorticoid levels. Front. Neuroendocrinol. 2017, 44, 83-102. [CrossRef] [PubMed]

10. Chen, C. Fitness Powered Brains: Optimize Your Productivity, Leadership and Performance; Brain \& Life Publishing: London, UK, 2017.

11. Sapolsky, R.M. Why Zebras Don't Get Ulcers: The Acclaimed Guide to Stress, Stress-Related Diseases, and Coping-Now Revised and Updated; Holt paperbacks: New York, NY, USA, 2004.

12. Sandi, C.; Haller, J. Stress and the social brain: Behavioural effects and neurobiological mechanisms. Nat. Rev. Neurosci. 2015, 16, 290. [CrossRef] [PubMed]

13. Randall, D.K. Dreamland: Adventures in the Strange Science of Sleep; WW Norton \& Company: New York, NY, USA, 2012.

14. Goldstein, A.N.; Walker, M.P. The role of sleep in emotional brain function. Annu. Rev. Clin. Psychol. 2014, 10, 679-708. [CrossRef] [PubMed]

15. Hackman, D.A.; Farah, M.J.; Meaney, M.J. Socioeconomic status and the brain: Mechanistic insights from human and animal research. Nat. Rev. Neurosci. 2010, 11, 651. [CrossRef] [PubMed]

16. Albrecht, G.; Sartore, G.M.; Connor, L.; Higginbotham, N.; Freeman, S.; Kelly, B.; Stain, H.; Tonna, A.; Pollard, G. Solastalgia: The distress caused by environmental change. Australas. Psychiatry 2007, 15, S95-S98. [CrossRef] [PubMed]

17. Clifford, A.; Lang, L.; Chen, R.; Anstey, K.J.; Seaton, A. Exposure to air pollution and cognitive functioning across the life course-A systematic literature review. Environ. Res. 2016, 147, 383-398. [CrossRef] [PubMed]

18. Casas, L.; Cox, B.; Bauwelinck, M.; Nemery, B.; Deboosere, P.; Nawrot, T.S. Does air pollution trigger suicide? A case-crossover analysis of suicide deaths over the life span. Eur. J. Epidemiol. 2017, 32, 973-981. [CrossRef] [PubMed]

19. Calderón-Garcidueñas, L.; Mora-Tiscareño, A.; Ontiveros, E.; Gómez-Garza, G.; Barragán-Mejía, G.; Broadway, J.; Chapman, S.; Valencia-Salazar, G.; Jewells, V.; Maronpot, R.R.; et al. Air pollution, cognitive deficits and brain abnormalities: A pilot study with children and dogs. Brain Cogn. 2008, 68, 117-127. [CrossRef] [PubMed] 
20. Wilker, E.H.; Preis, S.R.; Beiser, A.S.; Wolf, P.A.; Au, R.; Kloog, I.; Li, W.; Schwartz, J.; Koutrakis, P.; DeCarli, C.; et al. Long-term exposure to fine particulate matter, residential proximity to major roads and measures of brain structure. Stroke 2015, 46, 1161-1166. [CrossRef] [PubMed]

21. WHO (World Health Organization). World Health Statistics Data Visualizations Dashboard. Available online: http:/ / apps.who.int/gho/data/view.sdg.11-6-data-ctry?lang=en (accessed on 13 October 2018).

22. Block, M.L.; Calderón-Garcidueñas, L. Air pollution: Mechanisms of neuroinflammation and CNS disease. Trends Neurosci. 2009, 32, 506-516. [CrossRef] [PubMed]

23. Genc, S.; Zadeoglulari, Z.; Fuss, S.H.; Genc, K. The adverse effects of air pollution on the nervous system. J. Toxicol. 2012. [CrossRef] [PubMed]

24. Maher, B.A.; Ahmed, I.A.; Karloukovski, V.; MacLaren, D.A.; Foulds, P.G.; Allsop, D.; Mann, D.M.A.; Torres-Jardón, A.; Calderon-Garciduenas, L. Magnetite pollution nanoparticles in the human brain. Proc. Natl. Acad. Sci. USA 2016, 113, 10797-10801. [CrossRef] [PubMed]

25. Chen, C.; Nakagawa, S. Nature's Pathways on Human Health. In International Handbook of Forest Therapy. In International Handbook of Forest Therapy; 2018; in press.

26. Calderón-Garcidueñas, L.; Solt, A.C.; Henríquez-Roldán, C.; Torres-Jardón, R.; Nuse, B.; Herritt, L.; Villarreal-Calderón, R.; Osnaya, N.; Stone, I.; García, R.; et al. Long-Term air pollution exposure is associated with neuroinflammation, an altered innate immune response, disruption of the blood-brain barrier, ultrafine particulate deposition, and accumulation of amyloid $\beta-42$ and $\alpha$-synuclein in children and young adults. Toxicol. Pathol. 2008, 36, 289-310. [CrossRef] [PubMed]

27. Heneka, M.T.; Carson, M.J.; El Khoury, J.; Landreth, G.E.; Brosseron, F.; Feinstein, D.L.; Jacobs, A.H.; Wyss-Coray, T.; Vitorica, J.; Ransohoff, M.; et al. Neuroinflammation in Alzheimer's disease. Lancet Neurol. 2015, 14, 388-405. [CrossRef]

28. Iadecola, C. The pathobiology of vascular dementia. Neuron 2013, 80, 844-866. [CrossRef] [PubMed]

29. Hirsch, E.C.; Hunot, S. Neuroinflammation in Parkinson's disease: A target for neuroprotection? Lancet Neurol. 2009, 8, 382-397. [CrossRef]

30. Cacabelos, R. Parkinson's disease: from pathogenesis to pharmacogenomics. Int. J. Mol. Sci. 2017, $18,551$. [CrossRef] [PubMed]

31. Wohleb, E.S.; Franklin, T.; Iwata, M.; Duman, R.S. Integrating neuroimmune systems in the neurobiology of depression. Nat. Rev. Neurosci. 2016, 17, 497. [CrossRef] [PubMed]

32. Aizenstein, H.J.; Baskys, A.; Boldrini, M.; Butters, M.A.; Diniz, B.S.; Jaiswal, M.K.; Jellinger, K.A.; Kruglov, L.S.; Meshandin, I.A.; Mijajlovic, M.D.; et al. Vascular depression consensus report-A critical update. BMC Med. 2016, 14, 161. [CrossRef] [PubMed]

33. Monji, A.; Kato, T.A.; Mizoguchi, Y.; Horikawa, H.; Seki, Y.; Kasai, M.; Yamauchi, M.; Yamada, S.; Kanba, S. Neuroinflammation in schizophrenia especially focused on the role of microglia. Prog. Neuropsychopharmacol. Biol. Psych. 2013, 42, 115-121. [CrossRef] [PubMed]

34. Najjar, S.; Pahlajani, S.; De Sanctis, V.; Stern, J.N.; Najjar, A.; Chong, D. Neurovascular Unit Dysfunction and Blood-Brain Barrier Hyperpermeability Contribute to Schizophrenia Neurobiology: A Theoretical Integration of Clinical and Experimental Evidence. Front. Psychiatry 2017, 8, 83. [CrossRef] [PubMed]

35. Niu, Y.; Chen, R.; Xia, Y.; Cai, J.; Ying, Z.; Lin, Z.; Liu, C.; Chen, C.; Peng, L.; Zhao, Z.; et al. Fine particulate matter constituents and stress hormones in the hypothalamus-pituitary-adrenal axis. Environ. Int. 2018, 119, 186-192. [CrossRef] [PubMed]

36. Basner, M.; Babisch, W.; Davis, A.; Brink, M.; Clark, C.; Janssen, S.; Stansfeld, S. Auditory and non-auditory effects of noise on health. Lancet 2014, 383, 1325-1332. [CrossRef]

37. Berry, H.L.; Bowen, K.; Kjellstrom, T. Climate change and mental health: A causal pathways framework. Int. J. Public Health 2010, 55, 123-132. [CrossRef] [PubMed]

38. Chepesiuk, R. Missing the dark: Health effects of light pollution. Environ. Health Perspect. 2009, 117, A20. [CrossRef] [PubMed]

39. Selhub, E.M.; Logan, A.C. Your brain on Nature: The Science of Nature's Influence on Your Health, Happiness and Vitality; John Wiley \& Sons: Hoboken, NJ, USA, 2012.

40. Chen, C. Cleverland: The Science of How Nature Nurtures; Brain \& Life Publishing: London, UK, 2018.

41. Strosnider, H.; Kennedy, C.; Monti, M.; Yip, F. Rural and urban differences in air quality, 2008-2012, and community drinking water quality, 2010-2015-United States. MMWR Surveill. Summ. 2017, 66, 1. [CrossRef] [PubMed] 
42. Lederbogen, F.; Kirsch, P.; Haddad, L.; Streit, F.; Tost, H.; Schuch, P.; Wüst, S.; Pruessner, J.C.; Rietschel, M.; Deuschle, M.; et al. City living and urban upbringing affect neural social stress processing in humans. Nature 2011, 474, 498. [CrossRef] [PubMed]

43. Haddad, L.; Schäfer, A.; Streit, F.; Lederbogen, F.; Grimm, O.; Wüst, S.; Deuschle, M.; Kirsch, P.; Tost, H.; Meyer-Lindenberg, A. Brain structure correlates of urban upbringing, an environmental risk factor for schizophrenia. Schizophr. Bull. 2014, 41, 115-122. [CrossRef] [PubMed]

44. Park, B.J.; Tsunetsugu, Y.; Kasetani, T.; Hirano, H.; Kagawa, T.; Sato, M.; Miyazaki, Y. Physiological effects of shinrin-yoku (taking in the atmosphere of the forest)-Using salivary cortisol and cerebral activity as indicators-. J. Physiol. Anthropol. 2007, 26, 123-128. [CrossRef] [PubMed]

45. Park, S.; Song, C.; Oh, Y.A.; Miyazaki, Y.; Son, K.C. Comparison of physiological and psychological relaxation using measurements of heart rate variability, prefrontal cortex activity, and subjective indexes after completing tasks with and without foliage plants. Int. J. Environ. Res. Public Health 2017, $14,1087$. [CrossRef] [PubMed]

46. Bratman, G.N.; Hamilton, J.P.; Hahn, K.S.; Daily, G.C.; Gross, J.J. Nature experience reduces rumination and subgenual prefrontal cortex activation. Proc. Natl. Acad. Sci. USA 2015, 112, 8567-8572. [CrossRef] [PubMed]

47. Li, Q.; Morimoto, K.; Nakadai, A.; Inagaki, H.; Katsumata, M.; Shimizu, T.; Hirata, Y.; Hirata, K.; Suzuki, H.; Miyazaki, Y.; et al. Forest bathing enhances human natural killer activity and expression of anti-cancer proteins. Int. J. Immunopathol. Pharmacol. 2007, 20, 3-8. [CrossRef] [PubMed]

48. Mao, G.X.; Cao, Y.B.; Lan, X.G.; He, Z.H.; Chen, Z.M.; Wang, Y.Z.; Hu, X.-L.; Lv, Y.D.; Wang, G.-F.; Yan, J.; et al. Therapeutic effect of forest bathing on human hypertension in the elderly. J. Cardiol. 2012, 60, 495-502. [CrossRef] [PubMed]

49. Song, C.; Ikei, H.; Miyazaki, Y. Physiological effects of nature therapy: A review of the research in Japan. Int. J. Environ. Res. Public Health 2016, 13, 781. [CrossRef] [PubMed]

50. Kabisch, N.; van den Bosch, M.; Lafortezza, R. The health benefits of nature-based solutions to urbanization challenges for children and the elderly-A systematic review. Environ. Res. 2017, 159, 362-373. [CrossRef] [PubMed]

51. Frumkin, H.; Bratman, G.N.; Breslow, S.J.; Cochran, B.; Kahn, P.H., Jr.; Lawler, J.J.; Levin, P.S.; Tandon, P.S.; Varanasi, U.; Wolf, K.L.; et al. Nature contact and human health: A research agenda. Environ. Health Perspect. 2017, 125. [CrossRef] [PubMed]

52. Whitmee, S.; Haines, A.; Beyrer, C.; Boltz, F.; Capon, A.G.; de Souza Dias, B.F.; Ezeh, A.; Frumkin, H.; Gong, P.; Head, P.; et al. Safeguarding human health in the Anthropocene epoch: Report of The Rockefeller Foundation-Lancet Commission on planetary health. Lancet 2015, 386, 1973-2028. [CrossRef]

53. World Bank. PM2.5 Air Pollution, Mean Annual Exposure (Micrograms Per Cubic Meter). Available online: https:/ / data.worldbank.org/indicator/EN.ATM.PM25.MC.M3 (accessed on 13 October 2018).

54. WHO (World Health Organization). Air pollution. Available online: https://www.who.int/airpollution/en/ (accessed on 14 October 2018).

55. World Bank. Forest Area (\% of Land Area). Available online: https://data.worldbank.org/indicator/AG. LND.FRST.ZS (accessed on 15 October 2018).

56. Zhang, X.; Chen, X.; Zhang, X. The impact of exposure to air pollution on cognitive performance. Proc. Natl. Acad. Sci. USA 2018, 115, 9193-9197. [CrossRef] [PubMed]

57. Tyler, C.R.; Noor, S.; Young, T.L.; Rivero, V.; Sanchez, B.; Lucas, S.; Caldwell, K.K.; Milligan, E.D.; Campen, M.J. Aging Exacerbates Neuroinflammatory Outcomes Induced by Acute Ozone Exposure. Toxicol. Sci. 2018, 163, 123-139. [CrossRef] [PubMed]

58. United Nations. World Population Prospects: The 2017 Revision. Available online: http://www.un. org/en/development/desa/population/publications/pdf/ageing/WPA2017_Highlights.pdf (accessed on 15 October 2018).

59. Perera, F.; Herbstman, J. Prenatal environmental exposures, epigenetics, and disease. Reproductive Toxicol. 2011, 31, 363-373. [CrossRef] [PubMed]

60. Whiteford, H.A.; Ferrari, A.J.; Degenhardt, L.; Feigin, V.; Vos, T. The global burden of mental, neurological and substance use disorders: An analysis from the Global Burden of Disease Study 2010. PloS ONE 2015, 10, e0116820. [CrossRef] [PubMed] 
61. Feigin, V.L.; Abajobir, A.A.; Abate, K.H.; Abd-Allah, F.; Abdulle, A.M.; Abera, S.F.; Abyu, G.Y.; Ahmed, M.B.; Aichour, A.N.; Aichour, I.; et al. Global, regional, and national burden of neurological disorders during 1990-2015: A systematic analysis for the Global Burden of Disease Study 2015. Lancet Neurol. 2017, 16, 877-897. [CrossRef]

62. Pearce, D.; Markandya, A.; Barbier, E. Blueprint 1: For a Green Economy; Routledge: Abingdon, UK, 2013.

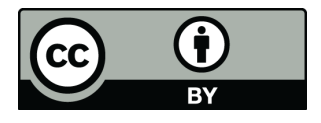

(c) 2018 by the authors. Licensee MDPI, Basel, Switzerland. This article is an open access article distributed under the terms and conditions of the Creative Commons Attribution (CC BY) license (http:/ / creativecommons.org/licenses/by/4.0/). 